\title{
Technology and Entrepreneurial Marketing Decisions During COVID-19
}

\author{
Mohammad Rashed Hasan Polas ${ }^{1}$ (D) Valliappan Raju ${ }^{1}$ (D)
}

Received: 28 April 2020/ Accepted: 5 February 2021/Published online: 10 March 2021

(C) Global Institute of Flexible Systems Management 2021

\begin{abstract}
The prime concern of this study is to explore how technology influences entrepreneurial marketing decisions during the world pandemic (COVID-19). The study uses a sample of 127 SMEs from Bangladesh. Data were collected by sending out questionnaires electronically and by mail. Smart PLS (SEM) 3.0 was used to analyse the data following the quantitative method. The study reveals positive and significant relationships between entrepreneurial opportunity recognition, opportunity development and opportunity exploitation with their entrepreneurial marketing decisions. It also claims that entrepreneurial passion mediates the relationship between entrepreneurial opportunity recognition and opportunity development with their entrepreneurial marketing decisions. However, entrepreneurial passion does not mediate the relationship between entrepreneurial opportunity exploitation and entrepreneurial marketing decisions. The study offers researchers a broader and more wide-ranging view of the importance of artificial intelligence in small firms. Researchers, educators and practitioners will benefit from the findings. The analyses are more complex and varied than the methodologies used in most of the limited previous research.
\end{abstract}

Keywords Bangladesh · COVID-19 · Entrepreneurial marketing decisions - Opportunity development . Opportunity exploitation - Opportunity recognition . Technology

Mohammad Rashed Hasan Polas

rashedhasanpalash@gmail.com

Valliappan Raju

valliappan008@gmail.com

1 Center for Post Graduate Studies, Limkokwing University of Creative Technology, 63000 Cyberjaya, Malaysia

\section{Introduction}

Technology is transforming the twenty-first century out of all recognition, with its value increasing day by day (Makridakis 2017; Vuong 2019; Sushil 2020). Technological advances in science are radically transforming the market and entrepreneurship world (Ranjan 2009; Jahanshahi et al. 2018a, b). Technology is not only penetrating a variety of aspects of our personal, day-to-day lives. It also has the potential to modernise and build business structures, inventive concepts, goods and services, and address dynamic problems in producing new outcomes for the massive growth of entrepreneurship (Dirican 2015; Ransbotham et al. 2018; Sushil 2019). With AI (artificial intelligence), entrepreneurship spreads, where knowledge is the fundamental basis of development to better understand the whole entrepreneurial situation, and it becomes necessary to analyse the entrepreneurship process in a new light (Wright and Schultz 2018; Polas et al. 2019b).

In the present era of revolutionary scientific technologies, businesses are not only developing innovative goods and services, they are also reshaping ventures, obscuring regional borders and stimulating the current regulatory structures (Brynjolfsson and Mcafee 2017; Klumpp 2018). The new markets that are powered by emerging innovations such as the block chain, mechanical technology and IoT (Internet of Things) are growing exponentially so that it appears to be impossible for business experts and professionals to keep pace. AI has an effect on developments in the fourth industrial revolution (Mekinjić 2019; Astuti et al. 2019). Knowledge, ideas, creativity and technological progress are still essential drivers for entrepreneurship and economic development today. Many firms need to use AI technology for revolutionary innovation that creates new 
entrepreneurship capacity and generates social and economic progress to create a better quality of life (Hjorth and Holt 2016; Kamishima et al. 2018). Governments, organisations and communities are also significantly influenced by AI. At present, $\mathrm{AI}$ is a facilitator and the instigator of a substantial degree of entrepreneurial recognition (Sushil 2018; Giménez-Figueroa et al. 2018; Obschonka and Audretsch 2019; Polas et al. 2020).

On the eve of 2020, uncertainty struck the worldwide economy because of the coronavirus (COVID-19) pandemic. This emerging issue affects entrepreneurial marketing decisions drastically as it indirectly influences social problems such as food crises, falling share prices, and export and import delays (Bhattacharjeea and Jahanshahi 2020; Zhang et al. 2020). This vulnerability, arising from COVID-19, has started in Wuhan, China, in the last quarter of 2019 and had spreaded worldwide by the first quarter of 2020. The confirmed positive cases continue to increase (Zhang et al. 2020; Bhattacharjeea and Jahanshahi 2020), with millions of people infected and killed by COVID-19, including in developing nations such as Bangladesh, India and Iran. This unexpected global pandemic has triggered production breaks in several manufacturing firms in the USA, Bangladesh, India and so on. It is a crisis for the upward economic flow of entrepreneurs, especially those with start-up businesses (Sushil 2017; Chen et al. 2020; Evans and Bahrami 2020; Kuckertz et al. 2020). As a result, entrepreneurs are forced to use technologies in making marketing decision, because they are now performing their office activities at a distance, online Technological developments are making our lives simpler and more secure during the pandemic, helping entrepreneurs to reduce their business operating costs. They can make their marketing decisions from home or remote locations, since they do not need to attend the office in person (Fisher et al. 2020; Mohmmed et al. 2020).

Currently, almost any organisation in any industry can suffer occasional loss or decrease in revenue (Rogers et al. 2020; Vagal et al. 2020) as a result of COVID-19. The current health emergency poses a significant weakness for Bangladesh, causing entrepreneurs to work at home when making their business decisions. It is difficult for anyone to make marketing decisions in person during the COVID-19 pandemic, since close contact with other people poses a health risk. In this situation, technology makes it faster and more efficient to improve entrepreneurial marketing decisions (Grange et al. 2020; Gössling et al. 2020; Polas et al. 2020). At the time of writing, some one million employees in Bangladesh are away from work, so technology is the only way to run the business. Owing to the cancellation of orders from customers, some entrepreneurs will have to close down new start-ups, while many retailers have raised the product price due to COVID-19. Socially oriented entrepreneurs continuously improve every single ethical decision in making their marketing decisions (Sushil, 2015; Jahanshahi et al. 2020) during the COVID-19 crisis. In this respect, they should rely on the technologies that execute their orders precisely and in a robust manner. In addition, technology would help them lower the operating costs of their businesses, sustaining them through this phase of the pandemic.

The key objective of this study is to evaluate how entrepreneurial marketing decisions might be made with the aid of technology in business, as a result of the COVID-19 pandemic. The research investigates its effect on the marketing decision-making process of technologybased entrepreneurs. It has found that entrepreneurs' opportunity recognition, opportunity development and opportunity exploitation have a positive and significant linkage with their entrepreneurial marketing decisions. Moreover, the study has found a positive and significant mediation effect of entrepreneurial passion on the relationship between opportunity recognition and development and marketing decisions, although not on the relationship between opportunity exploitation and entrepreneurial marketing decisions. This study gives researchers a more wide-ranging view of the importance of $\mathrm{AI}$ in small firms. Researchers, educators and practitioners will benefit from this paper. The study also contributes to business organisations where entrepreneurs might use technology to explore entrepreneurial opportunity recognition, opportunity development and opportunity exploitation regarding the marketing decisions affected by COVID-19.

Our cross-sectional study of 127 SMEs (small- and medium-sized enterprises) in Bangladesh reveals the role of technology resulting from COVID-19. The paper also adds to the increasing research on sustainable entrepreneurship by referring to recent applications for a deeper understanding of the use of technology by entrepreneurs due to COVID-19. This introduction is followed by a literature review and the development of hypotheses, then the research methodology including research design, measurement development, sampling and data collection, and data analysis. The findings, including demographic profiles of respondents, measurement of model assessment, discriminant validity, structural model assessment and hypothesis testing are then discussed. The outcomes of the study are discussed in the conclusion in relation to the use of technology in SMEs due to COVID-19 and past literature, and the implications of the study are presented. 


\section{Literature Review and Hypothesis Development}

\section{Opportunity Recognition and Entrepreneurial Marketing Decisions}

The first hypothesis proposes that entrepreneurial opportunity recognition through technology influences marketing decisions. Entrepreneurial opportunity recognition implies the capacity to identify states in which new products, resources, raw materials, markets and organising approaches can be familiarised by the creation of new means, ends or means-end relationships (Baker and Nelson, 2005; Short et al. 2009; Yang and Gabrielsson, 2017; Song et al. 2017; Dey et al. 2019; Polas et al. 2020). Sudden volatility has impacted the global economy as a result of COVID-19, with small businesses faring the worst. Entrepreneurs are seeking to cut business operating costs as well as protecting them from viruses, as physical fitness is paramount (Jahanshahi et al. 2018a; Morrish and Jones 2020).

In these circumstances, the key issue should be the implementation of business operations using technology (Raju and Phung 2018). Technology now plays a vital role in the business world, replacing human activities as it functions more specifically and seamlessly, and much more quickly (Dirican 2015; Glavas et al. 2017; Carter 2018). Managers of SMEs are used to making choices on their marketing processes arbitrarily and are increasingly using technologies (i.e. desktop computers, mobile phones, wifi, multimedia, video conferencing, etc.) during the pandemic. As top-level executives, entrepreneurs themselves find it impossible to make decisions without the aid of technology (Amabile et al. 1996; Brundage et al. 2018; Jahanshahi et al. 2018a; Polas et al. 2018; Oluwatayo \& Adetoro, 2020).

With the restrictions on movement due to COVID-19, technology contributes to entrepreneurial marketing decisions by investigating the probability of acknowledgment (Alqahtani and Uslay 2020; McCall, 2020; Bartlett and Burton, 2020). In this case, with people operating from their own homes, AI could become a prime tool, allowing entrepreneurs to make business decisions remotely (Rouhani et al. 2012; Dhingra et al. 2016; Ploum et al. 2018). In general, entrepreneurial recognition means that an incentive is a mixture of social factors and external conditions and the subjective opinions and ideas of the entrepreneur (Phillips and Tracey, 2007; Gilmore et al. 2020). There are possibilities for producing new goods, services, systems, business models and strategies that offer entrepreneurs the opportunity to profit from the gap between the cost of manufacturing and the price of revenue (Bojica et al. 2012; Werhahn et al. 2015; Crick et al. 2020; Sadiku-Dushi and Ramadani, 2020; Jahanshahi et al. 2020). The opportunities arise from various sources: emerging technologies, unresolved challenges, demand for products, business model development, restructuring of the industry, changing market perceptions, innovation and recombination of knowledge. In this way, the new growth of AI is an evolutionary progression of industry types, a source of entrepreneurial opportunities that has facilitated the enhancement of innovative AI-based goods and services (George et al. 2016; Omar et al. 2020; Brown and Rocha, 2020) during COVID-19.

The key argument is that the recognition of the business model is the focal point of the opportunity identification stage. It helps entrepreneurs to develop their strategies for realisation. It is a strategy for outsourcing the concept of an opportunity to the globe (Maine et al. 2015; Zeng et al. 2020). There remains a substantial link between the recognition of opportunities and entrepreneurial marketing decisions. As a result, the higher degree of entrepreneurial opportunity recognition has an impact on the marketing decisions. If entrepreneurs are able to understand the sale of goods or services with the aid of technology, it will have an effect on their marketing decisions (Cardon and Kirk 2015; Nur et al. 2020; Yigitcanlar et al. 2020), affecting the market research on their products or services during COVID-19. In addition, the COVID-19 business model demonstrates how the entrepreneur plans to create financial or social value with a new or updated product or service and to generate sales and benefit (Hills et al. 2008; Jahanshahi, et al. 2018b; Sardeshmukh and Smith-Nelson, 2011; Guo et al. 2016; Brown and Rocha 2020; Chalmers et al. 2020). When entrepreneurs make decisions, technology is a valuable assistant. Thus, we hypothesise that

H1 There is a positive and significant relationship between entrepreneurial opportunity recognition and marketing decisions with the help of technology in small firms.

\section{Opportunity Development and Entrepreneurial Marketing Decisions}

Our second hypothesis predicts a positive and significant relationship between entrepreneurial opportunity development and marketing decisions. Entrepreneurial opportunity development requires the development and planning of market demand for goods and services (Johanson and Vahlne, 2006; Brockman, 2014; Buheji and Ahmed, 2020; Paul and Chowdhury 2020). Technology increases the needs of consumers and the development of creative prerequisites (Rao et al. 1999; Buheji and Ahmed, 2020). Organisations are more dependent on technologies to gain competitive advantage, according to resource-based theory (Davidsson et al. 2006; Lockett et al. 2008; Jahanshahi et al. 2018b; Nur et al. 2020). The significance of this 
theory has grown as a result of COVID-19 movement restrictions around the world. Entrepreneurs monitor resources remotely. The necessary resources required during the period of launching an undertaking are referred to as entrepreneurial resources; the success of an enterprise depends heavily on resources and their use (Ardichvili et al. 2003; Hortoványi et al. 2006; Donthu and Gustafsson, 2020).

Another sign is that knowledge-based organisations have built up expertise through technology and are highly successful, improving individuals' awareness and creativity through research and development practices to create a stronger and better team (Chandler et al. 2005; Hmieleski and Baron, 2009; Brown et al. 2020; Chalmers et al. 2020) with restricted movement. AI-based technology has a very important role to play in knowledge-based entrepreneurship, remarkable in the degree to which it has gained and achieved competitive advantage (Brown, 2017; Obschonka and Audretsch, 2019; Polas et al. 2019a; Yigitcanlar et al. 2020) during COVID-19.

Innovation in entrepreneurship is important as the outcome ensures the goods or services are prepared for the market; before it ages, all innovation will assist in the production and dissemination process (Al-Atabi and DeBoer, 2014; Saiz-Alvarez et al. 2014; Sharma et al. 2020) during the COVID-19 pandemic. Any entrepreneurial aspiration requires to be subsidised in a variety of ways; at the stage of disclosure, the financial prerequisite could be the least, based on the scale of the venture, innovation and human capital, and the duration of the timeline for growth and the various sources of financing required to build the entrepreneurial initiative (Sarasvathy, 2003; Phillips and Tracey, 2007; Mogaji et al. 2020).

In particular, in the case of AI-based product validation carried out by prototyping, the creation of a fair product with appropriate functionality and market and input research, the outcome will be market-ready (GiménezFigueroa et al. 2018; Obschonka and Audretsch 2019; Etemad 2020) during COVID-19. There is a clear connection between entrepreneurial opportunity development and the marketing decisions. Greater opportunity development through market research has an effect on the marketing decisions (Treffers et al. 2017; Hoque and Awang 2019; Crick et al. 2020; Morrish and Jones 2020), especially during COVID-19. In this case, like a human brain, technology tends to solve the dilemma of decision making. It is easy to see that AI makes a major contribution to our everyday lives, in particular to entrepreneurs taking their marketing decisions during movement restrictions due to COVID-19 (Kim and Kim 2018; Sadiku-Dushi et al. 2019; Parameswar et al. 2020). Thus, we hypothesise that,
$\mathrm{H} 2$ There is a positive and significant relationship between entrepreneurial opportunity development and marketing decisions with the help of technology in small firms.

\section{Opportunity Exploitation and Entrepreneurial Marketing Decisions}

The third hypothesis assumes a positive and significant relationship between entrepreneurial opportunity exploitation and marketing decisions with the help of technology. Technology allows entrepreneurs to make decisions about the opportunity exploitation during the COVID-19 pandemic. It makes decision making more versatile and easier to determine sooner (Ranjan 2009; Žigienè et al. 2019; Samiei and Habibi, 2020) amid a global epidemic. In general, the exploration of opportunities is a crucial phase in the creation of an effective business in an entrepreneurial marketing process. The option of an entrepreneurial process implies a dedication to market entry (Makridakis, 2017; Patrício and Rieder, 2018; Matejun, 2018). Entrepreneurs who want to start exploitation must concentrate on a variety of key factors that will trigger success within the competitive environment (Vasilchenko and Morrish, 2011; Guo et al. 2018; Rogers et al. 2020) during COVID19 , but face vulnerability in doing so in the evaluation of the new product, especially during the period of COVID-19 movement control.

In addition, a new product (or administration) that creates or includes benefit for its customer or end-user is entitled to an opportunity (Cox and Durfee 2003; Nur et al. 2020). Unlike the existing goods, entrepreneurs using novel products are likely to face major vulnerabilities that cause them to make marketing decisions (Malaviya and Wadhwa 2005; Alvarez et al. 2013; Vlacic et al. 2019; Sharahiley, 2020) during COVID-19. In addition, the consumer demand for the new product depends, to some degree, on whether consumers hear about the new product and think it is relevant (Ucbasaran et al. 2003; Etemad, 2020; Zhang et al. 2020). The lack of knowledge of the firm's business offerings raises the sensitivity of the consumer to the buying decision. Given that individuals are ordinarily opposed to vulnerabilities (Mainela et al. 2014; Fink et al. 2020), we suggest that entrepreneurs can fix a portion of the weakness of consumer demand until they can determine if their new innovation is sufficiently relevant to be completely utilised throughout COVID-19. This is before customer vulnerability has been resolved; entrepreneurs will remain unsure about consumer demand (Alvedalen and Boschma, 2017; Gonzalez-Uribe and Wang, 2020) during the COVID-19 pandemic.

The process of opportunity exploitation is key in the decision making of entrepreneurial marketing especially 
with social activities. This involves launching an initiative that relies on the action plan by validating the product by getting it closer to the market and services. It is a period of sales development and market development (Choi et al. 2008; Wood and Pearson, 2009; Kabir 2018; Nouri and Ahmady, 2018). There is a significant relationship between entrepreneurial opportunity exploitation and the marketing decisions. The higher degree of opportunity exploitation is, the greater is the effect on entrepreneurial marketing decisions (Nouri and Ahmady, 2018; Clough et al. 2019; Crick et al. 2020). If an entrepreneur has the opportunity for exploitation, this makes possible the final decisions on selling of goods or services (Nouri et al. 2018; Morrish and Jones, 2020) during COVID-19.

Entrepreneurship is a social enterprise that focuses on being connected to various individuals in society. It starts with opportunity exploration to find financing, product improvement and marketing, and entrepreneurs need to employ various methods to receive help from their information networks, i.e. social networks using creativity to make deals, marketing and to enhance the product to the customer (Hmieleski and Baron, 2008; Feringa 2014; Yang 2018; Afshar; Sharahiley 2020) during COVID-19. So, we easily state that technology influences our daily life as well as the decision-making process of entrepreneurs. Thus, we hypothesise that:

H3 There is a positive and significant relationship between entrepreneurial opportunity exploitation and marketing decisions with the help of technology in small firms.

\section{The Mediating Role of Entrepreneurial Passion}

In the fourth, fifth and sixth hypotheses, we predict that entrepreneurial passion mediates the relationship between opportunity recognition, development and exploitation, and entrepreneurial marketing decisions. Technology typically leads to developing entrepreneurial passion. It helps to relieve them of added burdens in making their marketing decisions (De Koning 2003; Makridakis 2017; Costa et al. 2018; Ko et al. 2019). During the epidemic of COVID-19, entrepreneurs take decisions remotely. Only AI will help them collect the knowledge they need to make the decisions. Entrepreneurial enthusiasm is a distinctive emotion, even among entrepreneurs (Cardon et al. 2013; Cardon and Kirk 2015; Obschonka et al. 2019; Karimi 2020). Cardon et al. $(2009 \mathrm{a}, \mathrm{b})$ contend that individuals who experience entrepreneurial passion have optimistic, extraordinary emotions equal to the entrepreneurial practices they are involved in and a clear motivating urge to pursue those feelings that lead them to make the required decisions about their marketing strategies at home on the basis of COVID-19.

Furthermore, entrepreneurial passion as a state full of emotion points to one of the individual causes that will now and then contribute to solve those challenges relevant to the new business foundation (Cardon 2008; Biraglia and Kadile 2017; Afshar Jahanshahi 2019). Passion is likely to trigger the vitality needed for potential entrepreneurs to resolve difficult situations by handling weaknesses and mishaps in the pooling of financial, human and social capital (Cardon et al. 2009a, b; Sriyakul and Jermsittiparsert2019). As such, passion can, during the development of entrepreneurial intentions, be less involved in the actual formation of an undertaking, without fundamentally considering any possibilities or hindrances attached to it as a result of COVID-19. People may be engaged in their enterprise under the influence of inborn motivation, meaning that they are taking part in the movement because of a pleasure aspect (Dacin et al. 2010; Kiani et al. 2020). Being passionate about entrepreneurship in general may be a catalyst in starting a company. As a result, individuals who are passionate about an entrepreneurial career are likely to build up an intention to start a company (Chen et al. 2009; Miller et al. 2012; Santos and Cardon 2019; Hubner et al. 2019).

Moreover, a passion for creating value and making an impact is essential to the notion of an entrepreneur (Biraglia and Kadile 2017; Saif and Ghania 2020). The design of a new pursuit takes place after some time and the key step of this method is the formulation of entrepreneurial intentions, which desperately needs knowledge on the decision-making process. In addition, the entrepreneurial intention represents a person's passion for launching a business and preferring an elective career route to regular employment (Carsrud and Brännback, 2011; De Clercq et al. 2013; Nasiru et al. 2015; Li and Wu 2019; Anjum et al. 2019) during COVID-19. Entrepreneurial passion considers opportunity recognition, development and exploitation in the decisions on marketing products or services. Without passion, entrepreneurs will not be able to make their marketing decisions (Anjum et al. 2019; Saif and Ghania 2020).

As already established, marketing decisions are informed by opportunity recognition, opportunity development and opportunity exploitation (Fesharaki 2019; Boone et al. 2019), in that order. It is impossible, however, to continue these tasks during COVID-19 without the assistance of technology, which can be more reliable than human performance. As a result, entrepreneurs can save themselves from COVID-19 and reduce their operating costs. As explained above, a passion for entrepreneurial activity within a particular context will cause a contextrelated start-up of business through the recognition, 
development and exploitation of opportunities (Shan et al. 2020; Murnieks et al. 2020; Nummela et al. 2020). A general affective state of entrepreneurial passion implanted within a particular context is likely to result in an operation situated in an entrepreneurial spirit that strengthens any marketing decisions taken during COVID-19. It thus appears to be consistent to predict that entrepreneurial passion can lead people towards decisions (Treffers et al. 2017; Santos and Cardon 2019; Murnieks et al. 2020). In this case, it is now easy to understand that technology also increases entrepreneurial passion which later contributes to marketing decisions. Thus, we hypothesise that:

H4 Entrepreneurial passion mediates the relationship between entrepreneurial opportunity recognition and marketing decisions with the help of technology in small firms.

H5 Entrepreneurial passion mediates the relationship between entrepreneurial opportunity development and marketing decisions with the help of technology in small firms.

H6 Entrepreneurial passion mediates the relationship between entrepreneurial opportunity exploitation and marketing decisions with the help of technology in small firms.

\section{Research Methodology}

\section{Research Design}

This study has embraced positivism since this technique helps researchers to discover empirical knowledge using a hypothetical deductive method of observation (Jankowicz, 2005). The descriptive method of research was also practised as the study includes particular problems, specific assumptions and a detailed set of knowledge (Malhotra, 2004).

\section{Measurement Development}

In order to compare the different layouts, validated items were added and validated for this study. Both focus constructs for this model have been measured by literaturebased reflective constructs and are developed to simplify measurements using a Likert scale of five points varying from (1) 'strongly disagree' to (5) 'strongly agree'. Our 26-item questionnaire meets Hair et al.'s (2014) minimum requirements for a robust instrument. The model's five variables are as follows, with four items each from the specified sources: entrepreneurial opportunity recognition from Wang et al. (2013); opportunity development from Hayton et al. (2011); opportunity exploitation from Schwartz and Teach (2000); entrepreneurial passion from
Cardon et al. (2013); and entrepreneurial marketing decisions from Kilenthong et al. (2010).

\section{Sampling and Data Collection}

To collect the necessary data, we used stratified random sampling. The population was the entrepreneurs at small firms in Dhaka, the capital of Bangladesh. The questionnaire was the main source of primary data, distributed either directly, electronically, through friends, or by mail during movement restrictions due to the COVID-19 outbreak. 173 of the 259 questionnaires distributed were returned; 46 of these were incomplete, leaving a final sample of 127 , a response rate of $66.80 \%$. The questionnaire was divided into two sections, section I covering the respondents' demographic profiles and section II the items to measure the variables.

The questionnaire was translated from English to Bengali by a Bengali-speaking expert, and respondents could choose whether to answer the English or Bengali version. Before the final survey, a pilot study was conducted among a sample of 15 respondents who were excluded in the final survey. Section I collected data for the control variables: entrepreneur's gender, age, marital status, educational level, age of the firm and the type of industry. Section II measured the independent variables opportunity recognition, development and exploitation, with entrepreneurial passion as a mediator; and the dependent variable, entrepreneurial marketing decisions, using a five-point Likert scale: $1=$ highly disagree, 2 = disagree, $3=$ neutral, $4=$ agree, $5=$ highly agree). Smart PLS 3.0 was used to run the SEM (structural equation modelling) to assess the study model, following the quantitative method. To check on non-response bias, we used a time-trend extrapolation test (Armstrong and Overton, 1977): it is assumed that late respondents are more similar to non-respondents (first $25 \%$ ) with the late respondents (late $25 \%$ ). None of these tests provided evidence that our data are subject to nonresponse bias.

\section{Data Analysis}

Structural equation modelling (SEM) is commonly used to support mediation and evaluation of complex relationship (Hair et al. 2014; Zheng et al. 2011). In this study, hypotheses were checked with Smart PLS 3.0 instruments. The sample size is a key determinant for SEM and the minimum sample dimensions recommended by Hair et al. (2014) using the minimum R-squared method were exceeded in our case. Smart PLS 3.0 was used to verify the data analysis and evaluate the validity and reliability of the study model. 


\section{Results}

A unique data collection of 127 entrepreneurs from small firms in Dhaka was used, with Smart PLS 3.0 to test the model and outcomes of the study.

The demographic details are presented in Table 1. $81.89 \%$ of respondents were male; over a third $(34.65 \%)$ were aged $30-34$ years, a quarter $(24.41 \%) 35-39$ and a similar proportion (22.83\%) 40-44. Almost three-quarters $(73.23 \%)$ of the entrepreneurs were married, $13.39 \%$ of the respondents were educated to SSC (Secondary School Certificate) level and $26.77 \%$ to HSC (Higher Secondary Certificate); $44.09 \%$ had a bachelor's degree, and $15.75 \%$ were postgraduates. Over half $(51.97 \%)$ of the firms had been established for only $1-4$ years, $37.01 \%$ for $5-8$ years, and $11.02 \%$ for $9-12$ years. Finally, $17.32 \%$ of the firms belonged to the agricultural sector, $24.41 \%$ were in retail trade, $32.28 \%$ in wholesale trade, $14.96 \%$ in the manufacturing sector, and the remaining $11.02 \%$ were classified as service industries or 'other'.

\section{Measurement Model Assessment}

Model evaluation is an important part of any study that is focused on such measurements or assumptions. Table 2 shows the loading factors for items, AVE values, composite reliability (CR), Cronbach's alpha values, $R$ square values and NFI values.

Table 2 shows that the AVE value of every variable is above 0.50 , the values of CR and Cronbach's alpha are above 0.70 and the value of factor loadings is above 0.60 , all of which are within the accepted range, although the NFI value is above the accepted range at 0.913 . So, the conceptual model is best fit with the hypotheses. Table 2 also indicates the $\mathrm{R}^{2}$ values of the variances of the endogenous variable(s). This may be small $\left(\mathrm{R}^{2}=2 \%\right)$, medium $\left(R^{2}=13 \%\right)$ or large effect $\left(R^{2}=26 \%\right)$, and here, the entrepreneurial marketing decision is demonstrated by a large effect $(0.918$ or $91.8 \%)$ with independent variables. Entrepreneurial passion also has a large effect $(0.926$ or $92.6 \%$ ) on entrepreneurial marketing decisions.

\section{Discriminant Validity: Fornell-Larcker Criterion}

Table 3 displays the values of the correlations between the LV (latent variables) and the square roots of the AVE (average variance extracted) values in the main diagonal of the SEM. The determination of discriminant validity used the Fornell-Larcker model criteria (1981). In addition, the square root of the AVE (in bold) of all variables is the largest within a spectrum of $0.731-0.859$. Thus, the discriminatory validity of the variables is preserved and certified for this approximate research model.

\section{Structural Model Assessment}

Structural model evaluation is another critical aspect of assessing its validity, which was illustrated introducing Smart PLS 3.0. Using the resample 500 bootstrapping technique, $\mathrm{t}$-values and $\mathrm{R}^{2}$ were also used. Table 2 reflects

Table 1 Respondent's demographic profile

\begin{tabular}{|c|c|c|c|c|c|}
\hline Characteristics & Frequency & Percentage & Characteristics & Frequency & Percentage \\
\hline \multicolumn{3}{|l|}{ Entrepreneur gender } & \multicolumn{3}{|c|}{ Entrepreneur educational level } \\
\hline Male & 104 & 81.89 & $S S C$ & 17 & 13.39 \\
\hline Female & 23 & 18.11 & HSC & 34 & 26.77 \\
\hline \multicolumn{3}{|l|}{ Entrepreneur Age } & Under-graduate & 56 & 44.09 \\
\hline 25-29 Years & 6 & 4.72 & Post-graduate & 20 & 15.75 \\
\hline 30-34 Years & 44 & 34.65 & \multicolumn{3}{|l|}{ Firm Age } \\
\hline 35-39 Years & 31 & 24.41 & $1-4$ years & 66 & 51.97 \\
\hline 40-44 Years & 29 & 22.83 & $5-8$ years & 47 & 37.01 \\
\hline 45 Years or Above & 17 & 13.39 & $9-12$ years & 14 & 11.02 \\
\hline \multicolumn{3}{|c|}{ Entrepreneur Marital Status } & \multicolumn{3}{|l|}{13 years or above } \\
\hline Single & 29 & 22.83 & \multicolumn{3}{|l|}{ Industry } \\
\hline Married & 93 & 73.23 & Agriculture & 22 & 17.32 \\
\hline Divorced & 5 & 3.94 & Retail trade & 31 & 24.41 \\
\hline \multicolumn{3}{|l|}{ Separated } & Wholesale Trade & 41 & 32.28 \\
\hline \multirow{3}{*}{\multicolumn{3}{|c|}{ Window }} & Manufacturing & 19 & 14.96 \\
\hline & & & Services & 8 & 6.3 \\
\hline & & & Others & 6 & 4.72 \\
\hline \multicolumn{6}{|l|}{ Total-127 } \\
\hline
\end{tabular}


Table 2 Measurement of model assessment

\begin{tabular}{|c|c|c|c|c|c|c|c|}
\hline Constructs & Items & Loading & AVE & $\mathrm{CR}$ & Alpha & R-Square & NFI \\
\hline & OR1 & 0.849 & & & & & 0.913 \\
\hline & OR2 & 0.878 & & & & & \\
\hline \multirow[t]{4}{*}{ OR } & OR3 & 0.806 & 0.721 & 0.911 & 0.871 & & \\
\hline & OR4 & 0.859 & & & & & \\
\hline & OD5 & 0.878 & & & & & \\
\hline & OD6 & 0.721 & & & & & \\
\hline \multirow[t]{4}{*}{ OD } & OD7 & 0.862 & 0.691 & 0.899 & 0.854 & & \\
\hline & OD8 & 0.853 & & & & & \\
\hline & OE9 & 0.85 & & & & & \\
\hline & OE10 & 0.819 & & & & & \\
\hline \multirow[t]{4}{*}{$\mathrm{OE}$} & OE11 & 0.851 & 0.687 & 0.898 & 0.849 & & \\
\hline & OE12 & 0.793 & & & & & \\
\hline & EP13 & 0.868 & & & & & \\
\hline & EP14 & 0.875 & & & & & \\
\hline \multirow[t]{4}{*}{ EP } & EP15 & 0.833 & 0.738 & 0.918 & 0.882 & 0.926 & \\
\hline & EP16 & 0.86 & & & & & \\
\hline & EMD17 & 0.768 & & & & & \\
\hline & EMD18 & 0.839 & & & & & \\
\hline \multirow[t]{2}{*}{ EMD } & EMD19 & 0.805 & 0.692 & 0.918 & 0.888 & 0.918 & \\
\hline & EMD20 & 0.856 & & & & & \\
\hline
\end{tabular}

Opportunity Recognition, Opportunity Development (OD), Opportunity Exploitation (OE)

Entrepreneurial Passion (EP), Entrepreneurial Marketing Decisions (EMD)

Table 3 Values of correlations between the LV and square roots of the AVE values in the main diagonal in the SEM

\begin{tabular}{llllll}
\hline & Latent Variables (LV) & 1 & 2 & 3 & 4 \\
\hline 1 & $\begin{array}{l}\text { Entrepreneurial Marketing } \\
\text { Decisions }\end{array}$ & 0.832 & & & \\
& Entrepreneurial Passion & 0.543 & 0.859 & & \\
2 & Opportunity Development & 0.519 & 0.589 & 0.731 & 0.588 \\
4 & Opportunity Exploitation & 0.489 & 0.511 & 0.498 & 0.567 \\
5 & Opportunity Recognition & 0.397 & 0.455 & 0.748
\end{tabular}

*The diagonal are the square root of the AVE (in bold) of the latent variables and indicates the highest in any column or row

the outcomes of structural equation modelling (SEM analysis).

\section{Hypothesis Testing}

Table 4 shows the results of testing the direct and indirect effect hypotheses by running SEM. In the first hypothesis, we assumed a positive and significant association between entrepreneurial opportunity recognition and marketing decisions, and this is supported in Table $4(\beta=0.737$, $t=24.142, p<0.001)$. So, we conclude that a high degree of entrepreneur's opportunity recognition will enhance the entrepreneurial marketing decisions.

In the second hypothesis, we assumed a positive and significant association between entrepreneurial opportunity development and marketing decisions. Again, Table 4 supports this $(\beta=0.689, t=19.096, p<0.001)$. So, we conclude that a high degree of entrepreneurial opportunity development will enhance marketing decisions. In the third hypothesis, we predicted a positive and significant association between entrepreneurial opportunity exploitation and marketing decisions, also supported by the results presented in Table $4(\beta=0.719, t=21.613, p<0.001)$. So, we conclude that a high degree of entrepreneurial opportunity exploitation will enhance marketing decisions.

The remaining hypotheses propose that entrepreneurial passion mediates the association between the independent variables and entrepreneurial marketing decisions. Table 4 confirms this in the case of opportunity recognition $(\beta=0.517, \quad t=23.816, \quad p<0.001)$ and opportunity 
Table 4 Result of direct and indirect effect hypotheses

\begin{tabular}{|c|c|c|c|c|c|c|}
\hline Hypotheses & Relationship & Std Beta & SE & $\mathrm{t}$-value & $\mathrm{p}$ value & Decision \\
\hline H1 & $\mathrm{OR} \rightarrow \mathrm{EMD}$ & 0.737 & 0.031 & 24.142 & 0.000 & Supported \\
\hline $\mathrm{H} 2$ & $\mathrm{OD} \rightarrow \mathrm{EMD}$ & 0.689 & 0.036 & 19.096 & 0.000 & Supported \\
\hline $\mathrm{H} 3$ & $\mathrm{OE} \rightarrow \mathrm{EMD}$ & 0.719 & 0.033 & 21.613 & 0.000 & Supported \\
\hline $\mathrm{H} 4$ & $\mathrm{OR} \rightarrow \mathrm{EP} \rightarrow \mathrm{EMD}$ & 0.517 & 0.014 & 23.816 & 0.000 & Supported \\
\hline H5 & $\mathrm{OD} \rightarrow \mathrm{EP} \rightarrow \mathrm{EMD}$ & 0.497 & 0.016 & 26.377 & 0.000 & Supported \\
\hline H6 & $\mathrm{OE} \rightarrow \mathrm{EP} \rightarrow \mathrm{EMD}$ & 0.153 & 0.103 & 1.433 & 0.152 & Rejected \\
\hline
\end{tabular}

Opportunity Recognition, Opportunity Development (OD), Opportunity Exploitation (OE),

Entrepreneurial Passion (EP), Entrepreneurial Marketing Decisions (EMD)

development $(\beta=0.497, t=26.377, p<0.001)$, respectively, supporting hypotheses 4 and 5 . However, entrepreneurial passion does not mediate the relationship between entrepreneurial opportunity exploitation and marketing decisions $(\beta=0.153, t=1.433, p>0.05)$, so hypothesis 5 is rejected.

In a business environment, the physical security of employees is a primary concern (Zangana 2008; Wickramasekara and Baruah 2013) during COVID-19. The most commonly recognised organisational systems in internal marketing make working conditions friendlier by bringing employees closer to top management during the pandemic. Entrepreneurs are better placed to advise employees as to what practices or acts are remunerated, appreciated and even respected during COVID-19. As seen from Table 4, when an entrepreneur increases the recognition, development and exploitation of opportunities, marketing decisions are explicitly improved. Entrepreneurial passion also drives marketing decisions in the cases of recognition and exploitation of opportunities, although not opportunity development.

Our results also confirm that entrepreneurs are more innovative in organisations that can solve problems and extreme issues, face less strain and offer a sense of protection in overcoming obstacles during the outbreak of COVID-19. Finally, firms can boost their strategic position in the market by employing technologies to bind production more closely to their marketing decisions. In particular, our findings show the importance of organisations relying on technologies in making any decisions during the COVID-19 pandemic. Afshar Jahanshahi et al. (2020) discovered a growing number of employees in thinking and innovation management regions; however-in relation to the ability to have a strong effect on innovative work involvement - this impact is precisely at the beginning of both accounts. In this case, technology may replace certain employees with regard to innovation, innovative management of marketing decisions.

In a knowledge-based culture, firms are looking to explore alternatives to promoting creative activities in the entrepreneurial workplace (Carmeli and Schaubroeck, 2007; Stephens and Carmeli, 2017); greater dedication to inventiveness in the working atmosphere is recommended for organisations to better achieve market growth (Egan, 2005). In this situation, technology tends to make some marketing decisions more successful. It allows entrepreneurs to cultivate their imagination and to apply it at a distance during the COVID-19 pandemic. Entrepreneurs' innovative contribution to work makes it easier for companies to adapt to increasingly tempestuous markets (Zhou et al. 2012; Perry-Smith and Shalley, 2014) and increase their performance (Gong et al. 2012). As a result, both business researchers and high-level business managers are eager to learn how to promote entrepreneurial innovation and creativity during COVID-19 with the aid of technology. As a consequence, our observational evidence from entrepreneurs in Bangladesh recognises the essential role of a marketing decision-making culture in COVID-19forging a strong relationship with employees-as an approach to enhancing their inventive interaction in working remotely without personal contact.

\section{Conclusion and Implications of the Study}

In the present situation, technology is playing a crucial and undeniable role in our everyday lives. Many businesses, such as banking and manufacturing, have become highly automated. This also allows entrepreneurs to make marketing decisions after the outbreak of COVID-19 from remote locations, without physical personal contact. Entrepreneurs may be more relaxed if they can work from home with the aid of technology. Automation reduces jobs and associated costs and improves efficiency. There is a huge potential for companies to provide enormous quantities of information and extract knowledge from the gathered data, using data mining ad deep-learning algorithms. Within a short time, technology may replace people in virtually all companies. Entrepreneurs should use this knowledge to design a primary vision and strategic plan for 
the development process. Technology is encroaching ever further into the delivery of goods and services, and it is certain that the rapid pace of AI will facilitate further growth, market opportunities and competitive advantage.

We proposed six hypotheses, of which our findings support five. First, entrepreneurial opportunity recognition enhances the marketing decisions. It appears that in the COVID-19 pandemic enterprises with greater use of technology are helping to sustain cohesion between nature, society and their monetisation strategies. Since they acknowledge the use of technology as part of major entrepreneurial marketing decisions, they avoid decisions that degrade the context and the atmosphere (Grégoire et al. 2010; Song et al. 2017; Afshar Jahanshahi et al. 2019).

Secondly, we find that opportunity development enhances the marketing decisions. Entrepreneurship management researchers believe that the introduction of technology has a long-term effect and that technology will have an impact on sustainable enterprise activities in the future. Accordingly, our results suggest that entrepreneurs feel a greater commitment to future generations through the use of technologies during the COVID-19 pandemic, such as the management of natural resources, the effective implementation of diversity among employees, a safe supply of equipment and the prevention of inappropriate marketing decisions (Toghraee et al. 2017; Chandra, 2017; Yang, 2018).

Finally, we conclude that a high degree of entrepreneurial opportunity exploitation facilitates decision making with strong commitment. Previous results show that entrepreneurs who sincerely believe in opportunities avoid unethical behaviour that affects employees in the workplace, preferring more rational marketing decisions (Cardon and Kirk 2015; Chen and Liu 2020). Our results with small and medium-sized businesses suggest that entrepreneurs who genuinely believe in their opportunities are not only concerned with the internal working environment, but also prefer to take more sustainable action, both to ensure the external environment and through the use of technology during COVID-19 (Abd Hamid et al. 2018). Their findings show the future extension of the results. Overall, the strategic actions of entrepreneurs reflect their beliefs and conduct, leading to the implementation of technologybased marketing decisions (Clough et al. 2019) during the COVID-19 pandemic.

An ever-increasing number of businesses are realising the long-awaited benefits of $\mathrm{AI}$ and machine learning. $\mathrm{AI}$ in business intelligence is increasing daily, especially during the COVID-19 pandemic. From process automation to pattern analysis, AI has seen a wide variety of market uses in recent days (Haider Syed et al. 2020; Asadi and Tarokh, 2020). It also leads to new growth opportunities.
Organisations will now be able to use computer algorithms to identify patterns and expectations in vast stores of data and to settle for faster marketing decisions that might become serious in real time. AI operates across many industries, using accurate evidence and processes to complement a well-defined corporate strategy aligned with hierarchical culture and values, allowing companies to make marketing decisions during and after the current epidemic (Lanz and Sussman, 2020; Donthu and Gustafsson, 2020).

Technology, especially AI, plays a critical role in predicting customer behaviour and providing product recommendations. Its potential cannot be conveyed in words during the pandemic (Ting et al. 2020), in areas evolving rapidly with the aid of technology. Although companies typically need to sell and advertise their goods or services, investing serious money does not necessarily mean further leads and return deals (Lucas et al. 2020) during COVID19. To boost business practices with the goal of increasing competitiveness as a result of COVID-19, AI will be the next major development in business. Employing AI should enable organisations to identify, consider and understand their target purchasers and know what kind of products they may need at a certain point in time. Involving big data and technologies, marketers will now be able to estimate purchaser activity and monitor data-based campaigns in any disaster situation, with impressive results that would improve their marketing decisions (Shi et al. 2020; Ienca and Vayena, 2020).

Technology helps provide digital customer management by telephone and online robotics for the selling of goods and services. Customer service must be an integral capacity of a company to attract and maintain customers (Javaid et al. 2020). However, this implies large numbers of customer service personnel to deal with enquiries and provide assistance through customer chat-bots, as all customer enquiries should be carried out on a timely and reasonable basis, taking into account the needs of the user. In this situation, technology lets entrepreneurs focus on their marketing decisions in anticipation of the effects of COVID-19. As a consequence of COVID-19, consumers are reluctant to visit enterprises in person for fear of virus contamination (McCall, 2020). In this scenario, they can consume the respective services from their home via telephone; an online robot as AI will provide the services. In this way, technology lets entrepreneurs make marketing decisions relevant to the epidemic of COVID-19 or other global pandemics (Ivanov 2020; Naudé, 2020; Hossain et al. 2020).

Technology assists in data processing and makes any marketing decisions relevant to goods or services (Salman et al. 2020; Polas et al. 2020a). In order to settle crucial marketing decisions, each business depends on the data of 
Fig. 1 The framework of the study

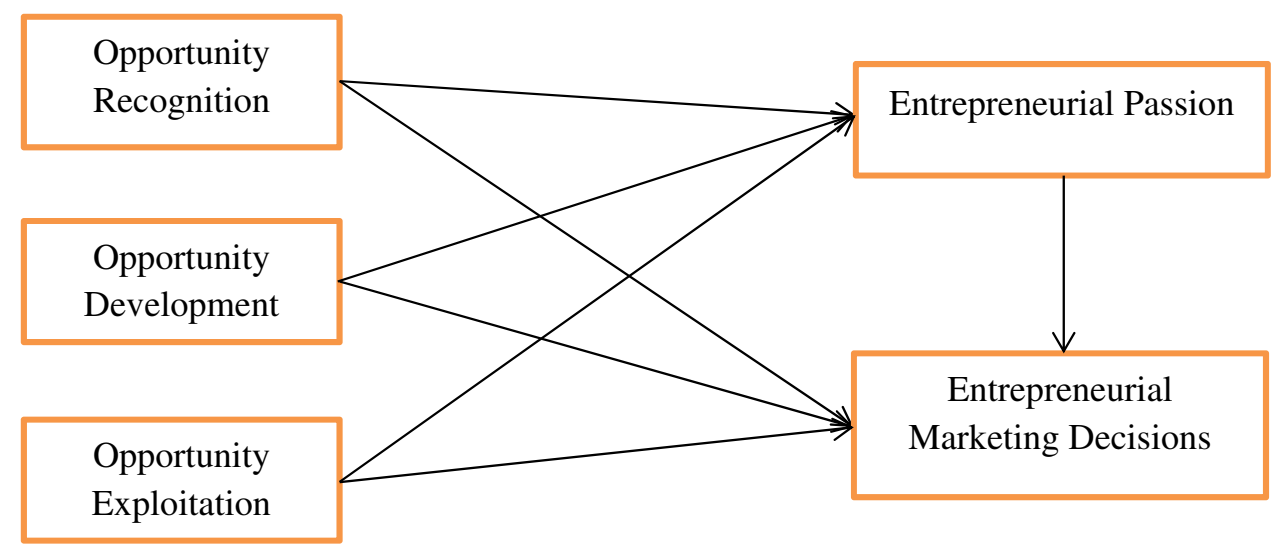

its customers, goods or services. Initially, the data is compiled, stored and eventually forwarded to the appropriate business department for further use. Due to the outbreak of COVID-19, filling forms, upgrading files, cross-referencing documents can be used in this case, as the need arises. With this advantage, many firms will use AIenabled data management systems to identify extortion, avoid cyber security threats and enhance their overall business activities during the pandemic (Goksel and Bozkurt, 2019; Di Vaio et al. 2020).

A sample of 127 Bangladeshi SMEs was used in this study, with Smart PLS 3.0 to analyse the data. A positive and significant relationship was found between entrepreneurial opportunity recognition, opportunity development and opportunity exploitation, and entrepreneurial marketing decisions, as predicted by some authors (Raju and Phung, 2018). Furthermore, entrepreneurial passion was found to mediate the relationships between opportunity recognition and development and entrepreneurial marketing decisions, although not opportunity exploitation. Entrepreneurs in small firms are using technology to support opportunity recognition, development and exploitation for their marketing decisions from their homes or other locations. The technology thus helps them to handle business during the crisis and is gradually becoming a crucial part of business worldwide.

Global economic development was reportedly slipping due to the SARS-CoV-2 pandemic (Bhattacharjee and Jahanshahi, 2020), and many researchers have noticed that at least one major pandemic has appeared every decade. Nowadays, any company may be vulnerable to more or less regular loss of sales (Gentile-Lüdecke et al. 2020) as a result of a global pandemic such as COVID-19. Specifically, Bangladeshi companies are now facing a major threat from the global health crisis. Specifically, emerging entrepreneurs have not been able to establish a business. In this sense, the use of technology would have a positive effect on marketing decisions. At the same time, sustainability is a frequently used but complex term, and not all entrepreneurs are equally concerned with social and environmental dilemmas. Our paper is taking a step towards emphasising the importance of technology for the sustainability of those companies. Policymakers must consider the importance of technology in strengthening the alignment of environmental and social challenges with recently established business models. Given that the ideals and activities of entrepreneurs are essential for the development of a market base in the social and environmental context; these provisions should be strengthened by government technical support programmes (Afshar Jahanshahi et al. 2019).

\section{Limitations and Directions for the Future Research}

Like other studies, this one has faced some difficulties. Firstly, the researchers experienced problems in collecting the questionnaires owing to non-cooperation from some potential respondents. For this reason, we employed 127 for this study. Secondly, many entrepreneurs did not respond to questionnaires by mail. This study is limited to one country; therefore, the difference in terms of its electronic structures and infrastructures is another limitation. Our findings suggest several possibilities for the future research. This study focuses only on the entrepreneurs of the firms. So, the future study may involve entrepreneurial team-level participants to investigate their marketing decision-making ability. Future studies may also include both objective and subjective data to support more trustworthy assumptions about the effect of entrepreneurial opportunity recognition on individual-level performance (Fig. 1).

Acknowledgment The authors would like to thank the data collection team and all the participants in the study.

Funding There is no research grant support for this study. 


\section{Compliance with Ethical Standards}

Conflict of interest The authors report no conflicts of interest in this work.

Ethical Standard The study followed all the standards established by the Human Research Ethics Committee of the Limkokwing University. The study was approved on ethics by the Limkokwing University Human Research Ethics Committee. Respondents were informed that it was voluntary to agree to complete the questionnaire and that they would have allowed their informed consent to participate and would have used the specifics for this study if they agreed to participate. They were also notified that the research was for academic purposes only, for potential policy implications.

\section{Appendix: Measurement Items}

\section{Opportunity Recognition (Wang et al. 2013):}

1. The industry offers many opportunities for technological innovation.

2. While going about routine day-to-day activities, I see potential new venture ideas all around me.

3. I have special alertness or sensitivity towards new venture opportunities.

4. Seeing potential new venture opportunities does not come very naturally to me.

\section{Opportunity Development (Hayton et al. 2011):}

1. We analysed the long-run opportunities and selected what we thought would provide the best returns with the help of technology.

2. We researched and selected target markets and did a meaningful competitive analysis using with help of technology.

3. The product/service that we used to launch this business was very similar to our original conception with the help of technology.

4. We experimented with different products and/or business models with the help of technology.

Opportunity Exploitation (Schwartz and Teach, 2000):

1. The firm produced a formal business plan before its establishment.

2. The firm developed formal marketing plans before its establishment.

3. To refine the original business concept, the firm employed an evaluation screen.

4. To refine the original business concept, the firm employed formal evaluation processes other than screens.

Entrepreneurial Passion (Cardon et al. 2013):

1. It is exciting to figure out new ways to solve unmet market needs that can be commercialised.
2. Searching for new ideas for products/services to offer is enjoyable to me.

3. I am motivated to figure out how to make the existing products/services better.

4. I really like finding the right people to market my product/service to.

Entrepreneurial Marketing Decisions (Kilenthong et al. 2010):

1. We aggressively try to expand our present customer base with the help of technology.

2. Our marketing efforts try to lead customers, rather than respond to them with the help of technology.

3. Most of our marketing decisions are based on what we learn from day-to-day customer contact with the help of technology.

4. We usually introduce new products and services based on the recommendations of our suppliers with the help of technology.

\section{References}

Abd Hamid, H., Everett, A. M., \& O'Kane, C. (2018). Ethnic migrant entrepreneurs' opportunity exploitation and cultural distance: A classification through a matrix of opportunities. Asian Academy of Management Journal, 23(1), 151-169.

Afshar Jahanshahi, A., Rauch, A., \& Gholami, H. (2019). Too dangerous to be an entrepreneur-warzone entrepreneurs' exit intention. In Academy of Management Proceedings (Vol. 2019, No. 1, p. 13477). Briarcliff Manor, NY 10510: Academy of Management.

Afshar Jahanshahi, A., Al-Gamrh, B., \& Gharleghi, B. (2020). Sustainable development in Iran post-sanction: Embracing green innovation by small and medium-sized enterprises. Sustainable Development, 28(4), 781-790.

Al-Atabi, M., \& DeBoer, J. (2014). Teaching entrepreneurship using massive open online course (MOOC). Technovation, 34(4), 261-264.

Alqahtani, N., \& Uslay, C. (2020). Entrepreneurial marketing and firm performance: Synthesis and conceptual development. Journal of Business Research, 113, 62-71.

Alvarez, S. A., Barney, J. B., \& Anderson, P. (2013). Forming and exploiting opportunities: The implications of discovery and creation processes for entrepreneurial and organizational research. Organization Science, 24(1), 301-317.

Alvedalen, J., \& Boschma, R. (2017). A critical review of entrepreneurial ecosystems research: Towards a future research agenda. European Planning Studies, 25(6), 887-903.

Amabile, T. M., Conti, R., Coon, H., Lazenby, J., \& Herron, M. (1996). Assessing the work environment for creativity. Academy of Management Journal, 39(5), 1154-1184.

Anjum, T., Ramzani, S. R., \& Nazar, N. (2019). Antecedents of entrepreneurial intentions: a study of business students from Universities of Pakistan. International Journal of Business and Psychology, 1(2), 72-88.

Ardichvili, A., Cardozo, R., \& Ray, S. (2003). A theory of entrepreneurial opportunity identification and development. Journal of Business Venturing, 18(1), 105-123. 
Armstrong, J. S., \& Overton, T. S. (1977). Estimating nonresponse bias in mail surveys. Journal of Marketing Research, 14(3), 396-402.

Asadi, J., \& Tarokh, F. (2020). How the artificial intelligence is helping to cure: The analytic means of health in current pandemic world. International Journal of Modern Engineering Technologies, 2(1), 1-5.

Astuti, B., Lestari, R., \& Bhakti, C. P. (2019). Student decisionmaking ability as a preparation for facing the industrial revolution 40. International Journal of Scientific \& Technology Research, 8(10), 1200-1204.

Baker, T., \& Nelson, R. E. (2005). Creating something from nothing: Resource construction through entrepreneurial bricolage. Administrative Science Quarterly, 50(3), 329-366.

Bartlett, S., \& Burton, D. (2020). Introduction to education studies. SAGE Publications Limited, London. Available at: https://books.google.com.my/books?hl=en\&lr=\&id=iLnjDwAA QBAJ\&oi=fnd\&pg=PP1\&dq=Bartlett, + S., $+\% 26+$ Burton, + D. $+(2020)$. + Introduction + to+education +studies. + SAGE+Publi cations +Limited,+London.\&ots=_nNQMNVVKr\&sig=d-P6U4 g_-AjrZiOmo_W9O8mw4X0\&redir_esc=y\#v=onepage \&q\&f=false

Bhattacharjeea, A., \& Jahanshahib, A. A. (2020). The COVID-19 outbreak brings spring season for translucent activity. Does it result in exogenous uncertainty for entrepreneurs and bound-less commodity pricing! Asian Journal of Multidisciplinary Studies, 8, 7.

Biraglia, A., \& Kadile, V. (2017). The role of entrepreneurial passion and creativity in developing entrepreneurial intentions: Insights from American homebrewers. Journal of Small Business Management, 55(1), 170-188.

Bojica, A. M., \& Fuentes, M. D. M. F. (2012). Knowledge acquisition and corporate entrepreneurship: Insights from Spanish SMEs in the ICT sector. Journal of World Business, 47(3), 397-408.

Boone, S., Andries, P., \& Clarysse, B. (2020). Does team entrepreneurial passion matter for relationship conflict and team performance? On the importance of fit between passion focus and venture development stage. Journal of Business Venturing, 35(5), 105984.

Brockman, B. K. (2014). Entrepreneurial alertness in opportunity identification and opportunity development. Journal of Business and Entrepreneurship, 26(2), 27-44.

Brown, T. E. (2017). Sensor-based entrepreneurship: A framework for developing new products and services. Business Horizons, 60(6), 819-830.

Brown, R., \& Rocha, A. (2020). Entrepreneurial uncertainty during the Covid-19 crisis: Mapping the temporal dynamics of entrepreneurial finance. Journal of Business Venturing Insights, 14, e00174.

Brown, R., Rocha, A., \& Cowling, M. (2020). Financing entrepreneurship in times of crisis: Exploring the impact of COVID-19 on the market for entrepreneurial finance in the United Kingdom. International Small Business Journal, 38(5), 380-390.

Brundage, M., Avin, S., Clark, J., Toner, H., Eckersley, P., Garfinkel, B., ... \& Anderson, H. (2018). The malicious use of artificial intelligence: Forecasting, prevention, and mitigation. arXiv preprint https://arxiv.org/abs/1802.07228.

Brynjolfsson, E., \& Mcafee, A. N. D. R. E. W. (2017). The business of artificial intelligence. Harvard Business Review, 1-20. Available: https://hbr.org/cover-story/2017/07/the-business-ofartificial-intelligence

Buheji, M., \& Ahmed, D. (2020). Foresight of Coronavirus (COVID19) opportunities for a better world. American Journal of Economics, 10(2), 97-108.

Cardon, M. S. (2008). Is passion contagious? The transference of entrepreneurial passion to employees. Human Resource Management Review, 18(2), 77-86.
Cardon, M. S., \& Kirk, C. P. (2015). Entrepreneurial passion as mediator of the self-efficacy to persistence relationship. Entrepreneurship Theory and Practice, 39(5), 1027-1050.

Cardon, M. S., Sudek, R., \& Mitteness, C. (2009a). The impact of perceived entrepreneurial passion on angel investing. Frontiers of Entrepreneurship Research, 29(2), 1-15.

Cardon, M. S., Wincent, J., Singh, J., \& Drnovsek, M. (2009b). The nature and experience of entrepreneurial passion. Academy of Management Review, 34(3), 511-532.

Cardon, M. S., Gregoire, D. A., Stevens, C. E., \& Patel, P. C. (2013). Measuring entrepreneurial passion: Conceptual foundations and scale validation. Journal of Business Venturing, 28(3), 373-396.

Carmeli, A., \& Schaubroeck, J. (2007). The influence of leaders' and other referents' normative expectations on individual involvement in creative work. The Leadership Quarterly, 18(1), 35-48.

Carsrud, A., \& Brännback, M. (2011). Entrepreneurial motivations: what do we still need to know? Journal of Small Business Management, 49(1), 9-26.

Carter, D. (2018). How real is the impact of artificial intelligence? The business information survey 2018. Business Information Review, 35(3), 99-115.

Chalmers, D., MacKenzie, N.G., Carter, S. (2020). Artificial intelligence and entrepreneurship: implications for venture creation in the fourth industrial revolution. Entrepreneurship Theory and Practice, Special Issue, pp.1-26. https://doi.org/10.1177/ 1042258720934581.

Chandler, G. N., Honig, B., \& Wiklund, J. (2005). Antecedents, moderators, and performance consequences of membership change in new venture teams. Journal of Business Venturing, 20(5), 705-725.

Chandra, Y. (2017). A time-based process model of international entrepreneurial opportunity evaluation. Journal of International Business Studies, 48(4), 423-451.

Chen, J., \& Liu, L. (2020). Customer participation, and green product innovation in SMEs: The mediating role of opportunity recognition and exploitation. Journal of Business Research, 119, $151-162$.

Chen, X. P., Yao, X., \& Kotha, S. (2009). Entrepreneur passion and preparedness in business plan presentations: a persuasion analysis of venture capitalists' funding decisions. Academy of Management Journal, 52(1), 199-214.

Chen, J., Zhang, S. X., Wang, Y., Jahanshahi, A. A., Dinani, M. M., Madavani, A. N., \& Nawaser, K. (2020). The curvilinear relationship between the age of adults and their mental health in Iran after its peak of COVID-19 cases. MedRxiv. https://doi.org/10.1101/2020.06.11.20128132.

Choi, Y. R., Lévesque, M., \& Shepherd, D. A. (2008). When should entrepreneurs expedite or delay opportunity exploitation? Journal of Business Venturing, 23(3), 333-355.

Clough, D. R., Fang, T. P., Vissa, B., \& Wu, A. (2019). Turning lead into gold: How do entrepreneurs mobilize resources to exploit opportunities? Academy of Management Annals, 13(1), 240-271.

Costa, S. F., Santos, S. C., Wach, D., \& Caetano, A. (2018). Recognizing opportunities across campus: The effects of cognitive training and entrepreneurial passion on the business opportunity prototype. Journal of Small Business Management, 56(1), 51-75.

Cox, J. S., \& Durfee, E. H. (2003). Discovering and exploiting synergy between hierarchical planning agents. In Proceedings of the second international joint conference on Autonomous agents and multiagent systems, pp. 281-288. doi:https://doi.org/ 10.1145/860575.860621.

Crick, J. M., Crick, D., \& Chaudhry, S. (2020). Entrepreneurial marketing decision-making in rapidly internationalising and deinternationalising start-up firms. Journal of Business Research, 113, 158-167. 
Dacin, P. A., Dacin, M. T., \& Matear, M. (2010). Social entrepreneurship: Why we don't need a new theory and how we move forward from here. Academy of Management Perspectives, 24(3), 37-57.

Davidsson, P., Delmar, F., \& Wiklund, J. (2006). Entrepreneurship as growth; growth as entrepreneurship. Entrepreneurship and the Growth of Firms, 1(2), 21-38.

De Koning, A. (2003). Opportunity development: A socio-cognitive perspective. Advances in Entrepreneurship, firm Emergence and Growth, 6, 265-314.

De Clercq, D., Honig, B., \& Martin, B. (2013). The roles of learning orientation and passion for work in the formation of entrepreneurial intention. International Small Business Journal, 31(6), 652-676.

Dey, S., Sharma, R. R. K., \& Pandey, B. K. (2019). Relationship of manufacturing flexibility with organizational strategy. Global Journal of Flexible Systems Management, 20(3), 237-256.

Dhingra, M., Jain, M., \& Jadon, R. S. (2016). Role of artificial intelligence in enterprise information security: a review. In 2016 fourth international conference on parallel, distributed and grid computing (PDGC) (pp. 188-191). IEEE. https://doi.org/10.1109/ PDGC.2016.7913142

Di Vaio, A., Boccia, F., Landriani, L., \& Palladino, R. (2020). Artificial intelligence in the agri-food system: rethinking sustainable business models in the COVID-19 scenario. Sustainability, 12(12), 4851.

Dirican, C. (2015). The impacts of robotics, artificial intelligence on business and economics. Procedia-Social and Behavioral Sciences, 195, 564-573.

Donthu, N., \& Gustafsson, A. (2020). Effects of COVID-19 on business and research. Journal of Business Research, 117, 284-289. https://doi.org/10.1016/j.jbusres.2020.06.008.

Egan, K. (2005). An imaginative approach to teaching. Eurasia Journal of Mathematics Science and Technology Education, $3(3), 247-248$.

Etemad, H. (2020). Managing uncertain consequences of a global crisis: SMEs encountering adversities, losses, and new opportunities. Journal of International Entrepreneurship, 18(2), $125-144$.

Evans, S., \& Bahrami, H. (2020). Super-flexibility in practice: Insights from a crisis. Global Journal of Flexible Systems Management, 21(3), 207-214.

Feringa, J. (2014). Entrepreneurship in architectural robotics: the simultaneity of craft, economics and design. Architectural Design, 84(3), 60-65.

Fesharaki, F. (2019). Entrepreneurial passion, self-efficacy, and spiritual intelligence among Iranian SME owner-managers. Psychological Studies, 64(4), 429-435.

Fink, M., Koller, M., Gartner, J., Floh, A., \& Harms, R. (2020). Effective entrepreneurial marketing on facebook - a longitudinal study. Journal of Business Research, 113, 149-157.

Fisher, G., Stevenson, R., \& Burnell, D. (2020). Permission to hustle: Igniting entrepreneurship in an organization. Journal of Business Venturing Insights, 14, e00173. https://doi.org/10.1016/ j.jbvi.2020.e00173.

Fornell, C., \& Larcker, D. F. (1981). Structural equation models with unobservable variables and measurement error: Algebra and statistics. Journal of Marketing Research, 18(3), 328-388.

Gentile-Lüdecke, S., de Oliveira, R. T., \& Paul, J. (2020). Does organizational structure facilitate inbound and outbound open innovation in SMEs? Small Business Economics, 55(4), $1091-1112$

George, N. M., Parida, V., Lahti, T., \& Wincent, J. (2016). A systematic literature review of entrepreneurial opportunity recognition: insights on influencing factors. International Entrepreneurship and Management Journal, 12(2), 309-350.
Gilmore, A., McAuley, A., Miles, M. P., \& Pattinson, H. (2020). Four questions of entrepreneurial marketing education: Perspectives of university educators. Journal of Business Research, 113, 189-197.

Giménez-Figueroa, R., Martín-Rojas, R., \& García-Morales, V. J. (2018). Business intelligence: An innovative technological way to influence corporate entrepreneurship. EntrepreneurshipDevelopment Tendencies and Empirical Approach, pp 113-132. https://doi.org/10.5772/intechopen.70538.

Glavas, C., Mathews, S., \& Bianchi, C. (2017). International opportunity recognition as a critical component for leveraging Internet capabilities and international market performance. Journal of International Entrepreneurship, 15(1), 1-35.

Goksel, N., \& Bozkurt, A. (2019). Artificial intelligence in education: Current insights and future perspectives. In Handbook of research on learning in the age of transhumanism (pp. 224-236). IGI Global. https://doi.org/10.4018/978-1-5225-84315.ch014

Gong, Y., Cheung, S. Y., Wang, M., \& Huang, J. C. (2012). Unfolding the proactive process for creativity: Integration of the employee proactivity, information exchange, and psychological safety perspectives. Journal of Management, 38(5), 1611-1633.

Gonzalez-Uribe, J., \& Wang, S. (2020). The Effects of Small-Firm Loan Guarantees in the UK: Insights for the COVID-19 Pandemic Crisis. Available at SSRN 3382280. https://www. fmg.ac.uk/sites/default/files/publications/DP795.pdf

Gössling, S., Scott, D., \& Hall, C. M. (2020). Pandemics, tourism and global change: A rapid assessment of COVID-19. Journal of Sustainable Tourism, 29(1), 1-20. https://doi.org/10.1080/ 09669582.2020.1758708.

Grange, E. S., Neil, E. J., Stoffel, M., Singh, A. P., Tseng, E., RescoSummers, K., \& Sutton, P. R. (2020). Responding to COVID-19: The UW medicine information technology services experience. Applied Clinical Informatics, 11(02), 265-275.

Grégoire, D. A., Barr, P. S., \& Shepherd, D. A. (2010). Cognitive processes of opportunity recognition: The role of structural alignment. Organization Science, 21(2), 413-431.

Guo, H., Su, Z., \& Ahlstrom, D. (2016). Business model innovation: The effects of exploratory orientation, opportunity recognition, and entrepreneurial bricolage in an emerging economy. Asia Pacific Journal of Management, 33(2), 533-549.

Guo, Z., Zhang, J., \& Gao, L. (2018). It is not a panacea! The conditional effect of bricolage in SME opportunity exploitation. $R \& D$ Management, 48(5), 603-614.

Haider, M., \& Khan, S. (2020). An artificial intelligence and NLP based Islamic FinTech model combining zakat and qardh-alhasan for countering the adverse impact of COVID 19 on SMEs and Individuals. International Journal of Economics and Business Administration, I(2), 351-364.

Hair, J. F., Sarstedt, M., Hopkins, L., \& Kuppelwieser, V. G. (2014). Partial least squares structural equation modeling (PLS-SEM). European Business Review, 26, 106-121.

Hayton, J., Chandler, G. N., \& DeTienne, D. R. (2011). Entrepreneurial opportunity identification and new firm development processes: a comparison of family and non-family new ventures. International Journal of Entrepreneurship and Innovation Management, 13(1), 12-31.

Hills, G. E., Hultman, C. M., \& Miles, M. P. (2008). The evolution and development of entrepreneurial marketing. Journal of Small Business Management, 46(1), 99-112.

Hjorth, D., \& Holt, R. (2016). It's entrepreneurship, not enterprise: Ai Weiwei as entrepreneur. Journal of Business Venturing Insights, 5, 50-54.

Hmieleski, K. M., \& Baron, R. A. (2008). Regulatory focus and new venture performance: a study of entrepreneurial opportunity exploitation under conditions of risk versus uncertainty. Strategic Entrepreneurship Journal, 2(4), 285-299. 
Hmieleski, K. M., \& Baron, R. A. (2009). Entrepreneurs' optimism and new venture performance: a social cognitive perspective. Academy of Management Journal, 52(3), 473-488.

Hoque, A. S. M. M., \& Awang, Z. (2019). Does gender difference play moderating role in the relationship between entrepreneurial marketing and Bangladeshi SME performance? Accounting, $5(1), 35-52$.

Hortoványi, L., Szabó, R. Z., \& Szabó, R. Z. (2006). Knowledge and organization: a network perspective. Society and Economy, 28(2), 165-179.

Hossain, M. I., Polas, M. R. H., Rahman, M. M., Islam, T., \& Jamadar, Y. (2020). An exploration of COVID-19 pandemic and its consequences on FMCG industry in Bangladesh. Journal of Management Info, 7(3), 145-155.

Hubner, S., Baum, M., \& Frese, M. (2020). Contagion of entrepreneurial passion: Effects on employee outcomes. Entrepreneurship Theory and Practice, 44(6), 1112-1140.

Ienca, M., \& Vayena, E. (2020). On the responsible use of digital data to tackle the COVID-19 pandemic. Nature Medicine, 26(4), $463-464$.

Ivanov, D. (2020). Predicting the impacts of epidemic outbreaks on global supply chains: a simulation-based analysis on the coronavirus outbreak (COVID-19/SARS-CoV-2) case. Transportation Research Part E: Logistics and Transportation Review, 136, 101922. https://doi.org/10.1016/j.tre.2020.101922.

Jahanshahi, A. A., Nawaser, K., \& Brem, A. (2018a). Corporate entrepreneurship strategy: an analysis of top management teams in SMEs. Baltic Journal of Management., 13(4), 528-543.

Jahanshahi, A. A., Brem, A., \& Shahabinezhad, M. (2018b). Does thinking style make a difference in environmental perception and orientation? Evidence from entrepreneurs in post-sanction Iran. Sustainability (Switzerland), 10(5), 1546.

Jahanshahi, A. A., Maghsoudi, T., \& Nawaser, K. (2020). The effects of social capital and psychological resilience on employees' positive work attitudes. International Journal of Human Resources Development and Management, 20(3-4), 231-251.

Jankowicz, D. (2005). The easy guide to repertory grids. Chichester: Wiley.

Javaid, M., Haleem, A., Vaishya, R., Bahl, S., Suman, R., \& Vaish, A. (2020). Industry 40 technologies and their applications in fighting COVID-19 pandemic. Diabetes and Metabolic Syndrome Clinical Research and Reviews, 14(4), 419-422.

Johanson, J., \& Vahlne, J. E. (2006). Commitment and opportunity development in the internationalization process: A note on the Uppsala internationalization process model. Management International Review, 46(2), 165-178.

Kabir, M. (2018). Entrepreneurship process in the era of Artificial Intelligence. In ACPI (pp. 174-182). Available at: https://books. google.com.my/books?hl=en\&lr=\&id=0nxTDwAAQBAJ\&oi= fnd \&pg $=$ PA174\&dq=Kabir, + M.+(2018,+March $).+$ Entreprene urship + process + in + the + era + of + Artificial+Intelligence. + In + ACPI+(pp.+174182).\&ots=gtmvquIDkZ\&sig=a9ObGwehur WLWpbas_8vkyjm6YE\&redir_esc $=\mathrm{y} \# \mathrm{v}=$ onepage $\& \mathrm{q} \& \mathrm{f}=$ false

Kamishima, Y., Gremmen, B., \& Akizawa, H. (2018). Can merging a capability approach with effectual processes help us define a permissible action range for AI robotics entrepreneurship? Philosophy of Management, 17(1), 97-113.

Karimi, S. (2020). The role of entrepreneurial passion in the formation of students' entrepreneurial intentions. Applied Economics, 52(3), 331-344.

Kiani, A., Ali, A., Kanwal, S., \& Wang, D. (2020). How and when entrepreneurs' passion lead to firms' radical innovation: Moderated mediation model. Technology Analysis and Strategic Management, 32(4), 443-456.

Kilenthong, P., Hills, G. E., Hultman, C., \& Sclove, S. L. (2010, September). Entrepreneurial marketing practice: Systematic relationships with firm age, firm size, and operator's status. In International symposium on marketing \& entrepreneurship (pp. 6-8). Available at: https://www.kmu-hsg.ch/rencon tres/Renc2010/Topics_2010/D/Rencontres_2010_Topic_D_Kiel enthong_Hills_Hultman_Sclove_f.pdf

Kim, J. J., \& Kim, I. (2018). Entrepreneurial marketing and airlinecause sponsorship congruence: Passenger sponsorship response to US-based full-service airlines. Sustainability, 10(7), 2359. https://doi.org/10.3390/su10072359.

Klumpp, M. (2018). Automation and artificial intelligence in business logistics systems: human reactions and collaboration requirements. International Journal of Logistics Research and Applications, 21(3), 224-242.

Ko, W. W., Liu, G., Wan Yusoff, W. T., \& Che Mat, C. R. (2019). Social entrepreneurial passion and social innovation performance. Nonprofit and Voluntary Sector Quarterly, 48(4), 759-783.

Kuckertz, A., Brändle, L., Gaudig, A., Hinderer, S., Reyes, C. A. M., Prochotta, A., \& Berger, E. S. (2020). Startups in times of crisisA rapid response to the COVID-19 pandemic. Journal of Business Venturing Insights. https://doi.org/10.1016/j.jbvi. 2020.e00169.

Lanz, J., \& Sussman, B. I. (2020). Information Security Program Management in a COVID-19 World. The CPA Journal, 90(6), $28-35$.

Li, L., \& Wu, D. (2019). Entrepreneurial education and students' entrepreneurial intention: does team cooperation matter? Journal of Global Entrepreneurship Research, 9(1), 35. https://doi.org/ 10.1186/s40497-019-0157-3.

Lockett, A., O'Shea, R. P., \& Wright, M. (2008). The development of the resource-based view: reflections from Birger Wernerfelt 1. Organization Studies, 29(8-9), 1125-1141.

Lucas, B., Elliot, B., \& Landman, T. (2020). Online information search during covid-19. arXiv preprint https://arxiv.org/2004. 07183.

Maine, E., Soh, P. H., \& Dos Santos, N. (2015). The role of entrepreneurial decision-making in opportunity creation and recognition. Technovation, 39, 53-72.

Mainela, T., Puhakka, V., \& Servais, P. (2014). The concept of international opportunity in international entrepreneurship: a review and a research agenda. International Journal of Management Reviews, 16(1), 105-129.

Makridakis, S. (2017). The forthcoming Artificial Intelligence (AI) revolution: Its impact on society and firms. Futures, 90, 46-60.

Malaviya, P., \& Wadhwa, S. (2005). Innovation management in organizational context: an empirical study. Global Journal of Flexible Systems Management, 6(2), 1-14.

Malhotra, D. (2004). Trust and reciprocity decisions: The differing perspectives of trustors and trusted parties. Organizational Behavior and Human Decision Processes, 94(2), 61-73.

Matejun, M. (2018). The process of opportunities exploration and exploitation in the development of SMES'innovativeness. Management and Production Engineering Review, 9(3), 3-15.

McCall, B. (2020). COVID-19 and artificial intelligence: protecting health-care workers and curbing the spread. The Lancet Digital Health, 2(4), e166-e167.

Mekinjić, B. (2019). The impact of industry 4.0 on the transformation of the banking sector. Journal of Contemporary Economics, 1(1), 6-28.

Miller, T. L., Grimes, M. G., McMullen, J. S., \& Vogus, T. J. (2012). Venturing for others with heart and head: How compassion encourages social entrepreneurship. Academy of Management Review, 37(4), 616-640.

Mogaji, E., Soetan, T. O., \& Kieu, T. A. (2020). The implications of artificial intelligence on the digital marketing of financial services to vulnerable customers. Australasian Marketing 
Journal (AMJ): Elsevier Australia. https://doi.org/10.1016/ j.ausmj.2020.05.003.

Mohmmed, A. O., Khidhir, B. A., Nazeer, A., \& Vijayan, V. J. (2020). Emergency remote teaching during Coronavirus pandemic: the current trend and future directive at Middle East College Oman. Innovative Infrastructure Solutions, 5(3), 1-11.

Morrish, S. C., \& Jones, R. (2020). Post-disaster business recovery: An entrepreneurial marketing perspective. Journal of Business Research, 113, 83-92.

Murnieks, C. Y., Cardon, M. S., \& Haynie, J. M. (2020). Fueling the fire: Examining identity centrality, affective interpersonal commitment and gender as drivers of entrepreneurial passion. Journal of Business Venturing, 35(1), 105909. https://doi.org/10.1016/j.jbusvent.2018.10.007.

Nasiru, A., Keat, O. Y., \& Bhatti, M. A. (2015). Influence of perceived university support, perceived effective entrepreneurship education, perceived creativity disposition, entrepreneurial passion for inventing and founding on entrepreneurial intention. Mediterranean Journal of Social Sciences, 6(3), 88-95.

Naudé, W. (2020). Artificial intelligence vs COVID-19: limitations, constraints and pitfalls. $A i$ \& Society, 1, 761-765. https://doi.org/10.1007/s00146-020-00978-0.

Nouri, P., \& Ahmady, A. (2018). A taxonomy of nascent entrepreneurs' marketing decisions in high-tech small businesses. Journal of Small Business Strategy, 28(3), 69-79.

Nouri, P., Imanipour, N., Talebi, K., \& Zali, M. (2018). Exploring positive outcomes of decision making biases in the field of entrepreneurial marketing. Qualitative Report, 23(6), $1364-1380$.

Nummela, N., Vissak, T., \& Francioni, B. (2020). The interplay of entrepreneurial and non-entrepreneurial internationalization: an illustrative case of an Italian SME. International Entrepreneurship and Management Journal, 1, 1-31. https://doi.org/ 10.1007/s11365-020-00673-y.

Nur, A. C., Burhanuddin, H., Niswaty, R., Cante, S. R., \& Akib, H. (2020). Opportunity to develop on enterpreneurial outbreaks of endemic COVID-19 in South Sulawesi Indonesia. Available at SSRN 3637252. https://doi.org/10.2139/ssrn.3637252.

Obschonka, M., \& Audretsch, D. B. (2019). Artificial intelligence and big data in entrepreneurship: a new era has begun. Small Business Economics. https://doi.org/10.1007/s11187-01900202-4.

Obschonka, M., Moeller, J., \& Goethner, M. (2019). Entrepreneurial passion and personality: the case of academic entrepreneurship. Frontiers in Psychology, 9, 2697. https://doi.org/10.3389/ fpsyg.2018.02697.

Oluwatayo, A. A., \& Adetoro, O. (2020). Influence of employee attributes, work context and human resource management practices on employee job engagement. Global Journal of Flexible Systems Management, 21(4), 295-308.

Omar, A. R. C., Ishak, S., \& Jusoh, M. A. (2020). The impact of Covid-19 Movement Control Order on SMEs' businesses and survival strategies. Geografia-Malaysian Journal of Society and Space, 16(2), 139-150.

Parameswar, N., Dhir, S., \& Sushil. (2020). Interpretive ranking of choice of interaction of parent firms post-international joint venture termination using TISM-IRP. Global Journal of Flexible Systems Management, 21(1), 1-16.

Patrício, D. I., \& Rieder, R. (2018). Computer vision and artificial intelligence in precision agriculture for grain crops: A systematic review. Computers and Electronics in Agriculture, 153, 69-81.

Paul, S. K., \& Chowdhury, P. (2020). Strategies for managing the impacts of disruptions during COVID-19: an example of toilet paper. Global Journal of Flexible Systems Management, 21(3), 283-293.
Perry-Smith, J. E., \& Shalley, C. E. (2014). A social composition view of team creativity: The role of member nationalityheterogeneous ties outside of the team. Organization Science, 25(5), 1434-1452.

Phillips, N., \& Tracey, P. (2007). Opportunity recognition, entrepreneurial capabilities and bricolage: Connecting institutional theory and entrepreneurship in strategic organization. Strategic Organization, 5(3), 313-320.

Ploum, L., Blok, V., Lans, T., \& Omta, O. (2018). Exploring the relation between individual moral antecedents and entrepreneurial opportunity recognition for sustainable development. Journal of Cleaner Production, 172, 1582-1591.

Polas, M. R. H., \& Afshar Jahanshahi, A. (2020a). The effects of individual characteristics on women intention to become social entrepreneurs?. Journal of Public Affairs. https://doi.org/ 10.1002/pa.2204

Polas, M. R. H., Jahanshahi, A. A., \& Rahman, M. L. (2018). Islamic branding as a tool for customer retention: Antecedents and consequences of islamic brand loyalty. International Journal of Islamic Marketing and Branding, 3(1), 1-14.

Polas, R. H., Bhattacharjee, A., Raju, V., \& Imtiaz, M. (2019a). Demographic factors influence on the tendency to become entrepreneur: Estimating the antecedents and consequences of entrepreneurial tendency. International Journal of Management, $8(1), 48-60$.

Polas, R. H., Imtiaz, M., Saboor, A., Hossain, N., Javed, M. A., \& Nianyu, L. (2019b). Assessing the perceived value of customers for being satisfied towards the sustainability of hypermarket in Malaysia. International Journal of Business, 6(5), 248-263.

Polas, M. R. H., Raju, V., Hossen, S. M., Karim, A. M., \& Tabash, M. I. (2020b). Customer's revisit intention: Empirical evidence on Gen-Z from Bangladesh towards halal restaurants. Journal of Public Affairs. https://doi.org/10.1002/pa.2572

Raju, V., \& Phung, P. S. (2018). Understanding flamboyancy of globalization through higher educational economics: Limkokwing Integrated Model on Economics (LIME). International Journal of Global Business, 11(2), 40-50.

Ranjan, J. (2009). Business intelligence: Concepts, components, techniques and benefits. Journal of Theoretical and Applied Information Technology, 9(1), 60-70.

Ransbotham, S., Gerbert, P., Reeves, M., Kiron, D., \& Spira, M. (2018). Artificial intelligence in business gets real. MIT sloan management review, September, 17,60280. Available at: https://sloanreview.mit.edu/projects/artificial-intelligence-inbusiness-gets-real/

Rao, S. S., Nahm, A., Shi, Z., Deng, X., \& Syamil, A. (1999). Artificial intelligence and expert systems applications in new product development-a survey. Journal of Intelligent Manufacturing, 10(3-4), 231-244.

Rogers, T. F., Zhao, F., Huang, D., Beutler, N., Burns, A., He, W. T., \& Yang, L. (2020). Isolation of potent SARS-CoV-2 neutralizing antibodies and protection from disease in a small animal model. Science, 369(6506), 956-963.

Rouhani, S., Ghazanfari, M., \& Jafari, M. (2012). Evaluation model of business intelligence for enterprise systems using fuzzy TOPSIS. Expert Systems with Applications, 39(3), 3764-3771.

Sadiku-Dushi, N., \& Ramadani, V. (2020). Entrepreneurial Marketing Mindset: What Entrepreneurs Should Know?. In Organizational Mindset of Entrepreneurship (pp. 181-210). Springer, Cham. doi:https://doi.org/10.1007/978-3-030-36951-4_9

Sadiku-Dushi, N., Dana, L. P., \& Ramadani, V. (2019). Entrepreneurial marketing dimensions and SMEs performance. Journal of Business Research, 100, 86-99.

Saif, H. A., \& Ghania, U. (2020). Need for achievement as a predictor of entrepreneurial behavior: The mediating role of 
entrepreneurial passion for founding and entrepreneurial interest. International Review of Management and Marketing, 10(1), $40-53$.

Saiz-Alvarez, J. M., Martínez, A. C., \& Martínez, C. C. A. (2014). An entrepreneurial well-being model based on GEM data for Spain. IJIMAI, 2(5), 38-47.

Salman, F. M., Abu-Naser, S. S., Alajrami, E., Abu-Nasser, B. S., \& Alashqar, B. A. (2020). COVID-19 detection using artificial intelligence. International Journal of Academic Engineering Research, 4(3), 18-25.

Samiei, E., \& Habibi, J. (2020). The mutual relation between Enterprise resource planning and knowledge management: A review. Global Journal of Flexible Systems Management, 21(1), 53-66.

Santos, S. C., \& Cardon, M. S. (2019). What's love got to do with it? Team entrepreneurial passion and performance in new venture teams. Entrepreneurship Theory and Practice, 43(3), 475-504.

Sarasvathy, S. D. (2003). Entrepreneurship as a science of the artificial. Journal of Economic Psychology, 24(2), 203-220.

Sardeshmukh, S. R., \& Smith-Nelson, R. M. (2011). Educating for an entrepreneurial career: Developing opportunity-recognition ability. Australian Journal of Career Development, 20(3), 47-55.

Schwartz, R. G., \& Teach, R. D. (2000). A model of opportunity recognition and exploitation: an empirical study of incubator firms. Journal of Research in Marketing and Entrepreneurship, 2(2), 93-107.

Shalender, K., \& Yadav, R. K. (2019). Strategic flexibility, manager personality, and firm performance: The case of Indian Automobile Industry. Global Journal of Flexible Systems Management, 20(1), 77-90.

Shan, B., Yan, S., Lu, X., \& Bi, D. (2020). Entrepreneurial Passion, Cognitive Bias, and Technology Commercialization of New Ventures. In Sustainability in the Entrepreneurial Ecosystem: Operating Mechanisms and Enterprise Growth (pp. 148-163). IGI Global. https://doi.org/10.4018/978-1-7998-3495-3.ch007

Sharahiley, S. M. (2020). Examining entrepreneurial intention of the Saudi Arabia's university students: Analyzing alternative integrated research model of TPB and EEM. Global Journal of Flexible Systems Management, 21(1), 67-84.

Sharma, H. B., Vanapalli, K. R., Cheela, V. S., Ranjan, V. P., Jaglan, A. K., Dubey, B., \& Bhattacharya, J. (2020). Challenges, opportunities, and innovations for effective solid waste management during and post COVID-19 pandemic. Resources, Conservation and Recycling, 162, 105052. https://doi.org/10.1016/ j.resconrec.2020.105052.

Shi, F., Wang, J., Shi, J., Wu, Z., Wang, Q., Tang, Z., \& Shen, D. (2020). Review of artificial intelligence techniques in imaging data acquisition, segmentation and diagnosis for covid-19. IEEE Reviews in Biomedical Engineering. https://doi.org/10.1109/ RBME.2020.2987975.

Short, J. C., Moss, T. W., \& Lumpkin, G. T. (2009). Research in social entrepreneurship: Past contributions and future opportunities. Strategic Entrepreneurship Journal, 3(2), 161-194.

Song, G., Min, S., Lee, S., \& Seo, Y. (2017). The effects of network reliance on opportunity recognition: A moderated mediation model of knowledge acquisition and entrepreneurial orientation. Technological Forecasting and Social Change, 117, 98-107.

Sriyakul, T., \& Jermsittiparsert, K. (2019). The mediating role of entrepreneurial passion in the relationship between entrepreneur education and entrepreneurial intention among university students in Thailand. International Journal of Innovation, Creativity and Change, 6(10), 193-212.

Stephens, J. P., \& Carmeli, A. (2017). Relational leadership and creativity: The effects of respectful engagement and caring on meaningfulness and creative work involvement. In Handbook of
Research on Leadership and Creativity: Edward Elgar Publishing.

Sushil. (2015). Creating flexibility through technological and attitudinal change. Global Journal of Flexible Systems Management, 16(4), 309-311.

Sushil. (2017). Does flexibility mitigate or enhance risk? Global Journal of Flexible Systems Management, 18(3), 169-171.

Sushil. (2018). Interpretive multi-criteria valuation of flexibility initiatives on direct value chain. Benchmarking An International Journal, 25(9), 3720-3742.

Sushil. (2019). Efficient interpretive ranking process incorporating implicit and transitive dominance relationships. Annals of Operations Research, 283(1-2), 1489-1516.

Sushil. (2020). Interpretive multi-criteria ranking of production systems with ordinal weights and transitive dominance relationships. Annals of Operations Research, 290(1-2), 677-695.

Ting, D. S. W., Carin, L., Dzau, V., \& Wong, T. Y. (2020). Digital technology and COVID-19. Nature Medicine, 26(4), 459-461.

Toghraee, M. T., Rezvani, M., Mobaraki, M. H., \& Farsi, J. Y. (2017). A systematic review on entrepreneurial marketing: three decade research on entrepreneurial marketing. International Journal of Applied Business and Economic Research, 15(8), 273-296.

Treffers, T., Welpe, I. M., Spörrle, M., \& Picot, A. O. (2017). The Role of Emotions and Cognitions in the Pre-entrepreneurial Process: What's New?. In Revisiting the Entrepreneurial Mind (pp. 243-259). Springer, Cham. https://doi.org/10.1007/ 978-3-319-45544-0_16

Ucbasaran, D., Wright, M., Westhead, P., \& Busenitz, L. W. (2003). The impact of entrepreneurial experience on opportunity identification and exploitation: Habitual and novice entrepreneurs. Advances in Entrepreneurship, Firm Emergence and Growth, 6, 231-263.

Vagal, A., Reeder, S. B., Sodickson, D. K., Goh, V., Bhujwalla, Z. M., \& Krupinski, E. A. (2020). The impact of the COVID-19 pandemic on the radiology research Enterprise: Radiology scientific expert panel. Radiology. https://doi.org/10.1148/radiol.2020201393.

Vasilchenko, E., \& Morrish, S. (2011). The role of entrepreneurial networks in the exploration and exploitation of internationalization opportunities by information and communication technology firms. Journal of International Marketing, 19(4), 88-105.

Vlacic, B., González-Loureiro, M., \& Eduardsen, J. (2019). The internationalization of SMEs: strategic choices under a cognitive approach. In Handbook of Research on Entrepreneurship, Innovation, and Internationalization (pp. 439-466). IGI global. https://doi.org/10.4018/978-1-5225-8479-7.ch017

Vuong, Q. H. (2019). Entrepreneurship: from economic complexities to interdisciplinary research. Management, 17(1), 117-129.

Wang, Y. L., Ellinger, A. D., \& Wu, Y. C. J. (2013). Entrepreneurial opportunity recognition: an empirical study of $\mathrm{R} \& \mathrm{D}$ personnel. Management Decision, 51(2), 248-266.

Werhahn, D., Mauer, R., Flatten, T. C., \& Brettel, M. (2015). Validating effectual orientation as strategic direction in the corporate context. European Management Journal, 33(5), 305-313.

Wickramasekara, P., \& Baruah, N. (2013). Labour migration for decent work in Afghanistan: Issues and challenges. Available at SSRN 2359158. https://ssrn.com/abstract $=2359158$ or doi: https://doi.org/10.2139/ssrn.2359158

Wood, M. S., \& Pearson, J. M. (2009). Taken on faith? The impact of uncertainty, knowledge relatedness, and richness of information on entrepreneurial opportunity exploitation. Journal of Leadership \& Organizational Studies, 16(2), 117-130.

Wright, S. A., \& Schultz, A. E. (2018). The rising tide of artificial intelligence and business automation: Developing an ethical framework. Business Horizons, 61(6), 823-832. 
Yang, M. (2018). International entrepreneurial marketing strategies of MNCs: Bricolage as practiced by marketing managers. International Business Review, 27(5), 1045-1056.

Yang, M., \& Gabrielsson, P. (2017). Entrepreneurial marketing of international high-tech business-to-business new ventures: A decision-making process perspective. Industrial Marketing Management, 64, 147-160.

Yigitcanlar, T., Desouza, K. C., Butler, L., \& Roozkhosh, F. (2020). Contributions and risks of artificial intelligence (AI) in building smarter cities: Insights from a systematic review of the literature. Energies, 13(6), 1473.

Zangana, H. (2008). Women and learning in the Iraqi war zone. International Journal of Lifelong Education, 27(2), 153-168.

Zeng, Z., Chen, P. J., \& Lew, A. A. (2020). From high-touch to hightech: COVID-19 drives robotics adoption. Tourism Geographies, 22(3), 724-734. https://doi.org/10.1080/14616688.2020.1762118

Zhang, S. X., Liu, J., Jahanshahi, A. A., Nawaser, K., Yousefi, A., Li, J., \& Sun, S. (2020). At the height of the storm: Healthcare staff's health conditions and job satisfaction and their associated predictors during the epidemic peak of COVID-19. Brain, Behavior, and Immunity.

Zhang, S. X., Sun, S., Jahanshahi, A. A., Alvarez-Risco, A., Ibarra, V. G., Li, J., \& Patty-Tito, R. M. (2020). Developing and testing a measure of COVID-19 Organizational Support of Healthcare Workers-Results from Peru, Ecuador, and Bolivia. Psychiatry Research, 113174.

Zheng, H., \& Lu, H. (2011). Effect of microwave pretreatment on the kinetics of ascorbic acid degradation and peroxidase inactivation in different parts of green asparagus (Asparagus officinalis L.) during water blanching. Food Chemistry, 128(4), 1087-1093.

Zhou, Q., Hirst, G., \& Shipton, H. (2012). Promoting creativity at work: The role of problem-solving demand. Applied Psychology, 61(1), 56-80.

Žigienè, G., Rybakovas, E., \& Alzbutas, R. (2019). Artificial Intelligence Based Commercial Risk Management Framework for SMEs. Sustainability, 11(16), 4501. https://doi.org/ 10.3390/su11164501.

Publisher's Note Springer Nature remains neutral with regard to jurisdictional claims in published maps and institutional affiliations.

\section{Key Questions}

1. How does technology influence entrepreneurial marketing decisions during the world pandemic (COVID-19)?

2. What are the factors that affect the entrepreneurial marketing decisions during the world pandemic (COVID-19)?

3. What is the importance of artificial intelligence in small firms?

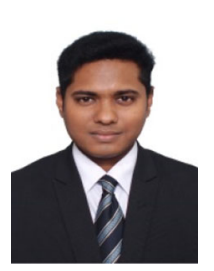

Mohammad Rashed Hasan Polas is a PhD candidate of Management at the Center for Post Graduate Studies, Limkokwing University of Creative Technology, Malaysia. $\mathrm{He}$ is also an affiliated researcher in Universidad Católica Los Ángeles de Chimbote, Instituto de Investigación, Chimbote, Peru. Moreover, he is the author of several papers in Journal of Enterprising Communities, Journal of Public Affairs, and International Journal of Management Practice and so on. He participated in several national and international conferences/seminars. He is an active editorial board member at several international reputed journals. His research interests lie in Artificial Intelligence, Entrepreneurship, Islamic Branding, Tourism, and Sustainability.

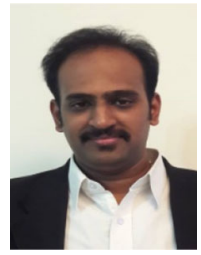

Assoc. Prof. Dr. Valliappan Raju is currently teaching at the Center for Post Graduate Studies in Limkokwing University of Creative Technology, Malaysia. He specializes in teaching Research Methodology to doctoral researchers. Prof. Vally is also a Visiting Research Scholar in De Monfort University, UK. He proudly serves as a member of Oxford Philosophical Society in Oxford and is appointed as an External Examiner for assessing Ph.D Viva Voce at the Malaysian Public Universities. Over the years, many researchers have obtained their Ph.D under his supervision. He has published over 250 manuscripts; numerous among them are indexed in Scopus with him as the principal author and author of "Fundamentals of Thesis" book. He actively reviews Q1 journals and World Bank Conference journals, USA. His research interests remain in Entrepreneurship, Economics and Artificial Intelligence. 